Portland State University

PDXScholar

Engineering and Technology Management

Faculty Publications and Presentations

Engineering and Technology Management

2014

\title{
Exploring Linkage of Quality Management to Innovation
}

Scott A. Leavengood

Oregon State University

Timothy R. Anderson

Portland State University, tim.anderson@pdx.edu

Tugrul Unsal Daim

Portland State University, tugrul@etm.pdx.edu

Follow this and additional works at: https://pdxscholar.library.pdx.edu/etm_fac

Part of the Engineering Commons

Let us know how access to this document benefits you.

\section{Citation Details}

Leavengood, Scott A.; Anderson, Timothy R.; and Daim, Tugrul Unsal, "Exploring Linkage of Quality Management to Innovation" (2014). Engineering and Technology Management Faculty Publications and Presentations. 50.

https://pdxscholar.library.pdx.edu/etm_fac/50

This Post-Print is brought to you for free and open access. It has been accepted for inclusion in Engineering and Technology Management Faculty Publications and Presentations by an authorized administrator of PDXScholar. Please contact us if we can make this document more accessible: pdxscholar@pdx.edu. 


\title{
Exploring linkage of Quality Management to Innovation
}

\author{
Scott Leavengood ${ }^{1}$, Timothy R. Anderson ${ }^{2}$, Tugrul U. Daim ${ }^{2}$ \\ ${ }^{1}$ Oregon State University, Wood Science \& Engineering Dept., \\ Corvallis, OR 97331 USA \\ ${ }^{2}$ Portland State University, Engineering \& Technology Management Dept., Portland, OR 97207 \\ USA
}

\begin{abstract}
In many business sectors today, focus on quality as a competitive tool is being replaced by a focus on innovation. Research exploring connections between quality management, innovation, and company performance suggests that quality is 'necessary but insufficient' in business today. In short, managers need to know how to adapt their quality management practices to achieve innovation performance in addition to quality performance.

West coast U.S. forest products manufacturers were surveyed about their quality management practices and performance with respect to both quality and innovation. Results were analyzed to identify two categories of high-performing firms: those achieving primarily quality outcomes and those achieving both quality and innovation outcomes. Executives from firms in each category were interviewed to provide detail on management practices.

Results suggest firms must first change how they view innovation; firms that were primarily focused on quality rather than innovation viewed innovation as an end rather than the means to some other business goal. The most significant finding is related to how firms interact with customers - firms focused on innovation proactively seek to identify and meet customers' needs whereas quality-focused firms primarily emphasize reacting to customer complaints. Findings suggest several areas where managers can focus to improve innovation performance.
\end{abstract}

Keywords: innovation, quality management, best management practices 


\section{Introduction}

In many business sectors today, focus on quality as a competitive strategy is being replaced by a focus on innovation. This has led some in the quality profession to pose the question 'is quality dead?' (McManus, 1999). While most would agree that quality will always be critical to competitiveness, innovation is likely to continue to grow in importance as a key element of competitive strategy. Therefore, a key challenge confronting organizations is determining how to integrate the two, that is, how to manage for both quality and innovation performance. This is particularly so in small to medium-sized organizations that typically lack the staff and/or resources to devote specific individuals, let alone departments, to novation management and quality management.

The American Society for Quality (ASQ) defines quality as:

"A subjective term for which each person has his or her own definition. In technical usage, quality can have two meanings: 1 . the characteristics of a product or service that bear on its ability to satisfy stated or implied needs. 2. a product or service free of deficiencies.” (Anonymous, 2006). The rapid development of quality methods in Japan following the war had a dramatic and positive impact on the quality of Japanese goods. As export of these goods increased, quality rose in importance as a source of competitive advantage. Garvin (1983) conducted a groundbreaking study comparing U.S. and Japanese manufacturers of room air conditioners. He reported that “...the poorest Japanese company (with respect to quality) typically had a failure rate less than half that of the best U.S. manufacturer.” By the 1980s, the U.S. industry, automakers and electronics firms in particular, was under significant pressure to improve quality (NBC, 1980). TQM as a management philosophy spread rapidly around the 
globe in the 1980s (Goldman, 2005). Flynn et al. (1994) define TQM as, "an integrated approach to achieving and sustaining high quality output, focusing on the maintenance and continuous improvement of processes and defect prevention at all levels and in all functions of the organization, in order to meet or exceed customer expectations”. This systems view of quality management is important to state explicitly in that one of the evolutionary improvements to TQM has been to expand the view of the system from encompassing 'sales to shipping' (i.e., the internal view) to include the company, its suppliers, and its customers (the external view) and even beyond to communities and the environment (NIST, 2009).

However, we must first ask, is it even feasible to integrate quality and innovation; are these complementary or competing objectives? The answer to this, at least in part, will depend on a company's approach to quality management. That is, quality management is not a static set of tools and techniques. Quality management has changed as manufacturing practices and processes have changed. And even within the set of practices known as Total Quality Management (TQM), there are widely varying approaches and areas of emphasis. Therefore, prior to discussing the feasibility of integrating quality and innovation, we first address the varying approaches to TQM.

\section{Varying Approaches to TQM}

At its core, TQM is based on three fundamental principles:

1. Focus on customers and stakeholders;

2. Participation and teamwork by everyone in the organization; and 
3. A process focus supported by continuous improvement and learning (Evans and Lindsay, 2002).

While these three principles serve as a simple means to define the guiding principles of TQM, they lack sufficient detail to define key practices companies use in implementing TQM. The U.S. Malcolm Baldrige National Quality Award (MBNQA) is often used as the conceptual framework for defining the key practices in TQM (Ahire et al., 1995, Black and Porter, 1995). The seven criteria that comprise the MBNQA include Leadership; Strategic Planning; Customer Focus; Measurement, Analysis, and Knowledge Management; Workforce Focus; Operations Focus; and Results (NIST, 2009).

Given the broad nature of these principles and practices, the emphasis placed by individual firms on each element varies widely. In fact, several TQM researchers have addressed the concept of dualities within TQM. Lewis et al. (Lewis et al., 2006a and b) explored one such duality - the so-called 'soft vs. hard tools' or factors of TQM. The authors defined soft factors as including customer focus and satisfaction, people training, top management commitment, teamwork, employee involvement, and supplier management. Hard factors included continuous improvement and innovation, information and performance measurement, process management, strategic planning, process control, and product and service design.

A second type of duality within TQM is the scope of implementation of TQM in a firm. From the start, the 'total' in Total Quality Management indicated the goal of focusing quality improvement efforts companywide. Regardless, years of quality efforts being focused solely on 
the plant floor, combined with challenges in adapting quality methods to non-manufacturing applications, led to slow spread of TQM throughout organizations (Evans and Lindsay, 2002). Along these lines, McAdam et al. (McAdam et al., 1998) state that the literature on TQM divides TQM into two categories - 'holistic TQM' and 'continuous improvement TQM.'

The third duality within TQM involves several topics related to internal vs. external focus. At one level, an internal focus emphasizes process improvement and an external focus emphasizes customer focus. And companies may either take a reactive or a proactive approach to customer needs. Additionally, within the concept of external focus, there are firms that view their firm's external environment as a 'closed system', i.e., customers and suppliers with whom they have direct business relationships. Firms that take more of an 'open system' view allow for consideration of a much broader picture of the company context, e.g., end consumers, communities where products will be used, and environmental impacts (Kekale and Kekale, 1995; McAdam et al., 1998; Sitkin et al., 1994; Fotopoulos and Psomas, 2009).

In summary, there are varying approaches to implementing TQM including use of hard vs. soft tools and techniques, scope of implementation, and internal vs. external focus. These dualities may be conceived of as varying levels of emphasis on the three fundamental principles of TQM presented above. In the context of quality and innovation, the question is, are there specific approaches to implementing TQM that lead to quality as well as innovation performance? Or again, is such a goal even feasible? 


\section{Quality and Innovation Tradeoffs}

Innovation is now widely recognized as a key factor to long-term competitiveness (Cooper, 1996). Innovation is often focused on attracting new customers; innovative firms acknowledge the risk of paying too much attention to satisfying existing customers at the expense of neglecting to stay attuned to the changing business environment. Some say that a qualityoriented culture in a firm may be counter-productive to fostering a culture focused on innovation (Sitkin et al., 1994; Cole and Matsumiya, 2007 and 2008; Prajogo and Sohal, 2001).

Quality and innovation have traditionally been seen as competing rather than complementary goals with various tradeoffs implied to achieve one goal vs. the other (Kanji, 1996, Samaha, 1996). As McAdam et al. (McAdam et al., 1998) stated, "Quality is doing things better; innovation is doing things differently." For example, some have argued that quality management focuses on incremental improvement and satisfying existing customers whereas innovation management emphasizes breakthrough improvements in products and processes and focusing on acquiring new customers (Sethi and Sethi, 2009, Sitkin et al., 1994).

In recent years, several researchers have explored the relationships between quality management, innovation, and company performance (Bossink, 2002, Hoang et al., 2006, Prajogo and Sohal, 2003, Prajogo and Sohal, 2004, Prajogo and Sohal, 2006b, Prajogo and Sohal, 2006a, Singh and Smith, 2004; Martinez Costa and Martinez Lorente, 2008; Liao et al., 2010 ). In general, the research has shown positive correlations such as a supporting role for quality in the management of innovation, suggestions that TQM lays the foundation for innovation, and straightforward assessments that TQM significantly and positively impacts quality and innovation performance. 
Results are often framed in terms of the dualities presented above - potential impact of the use of hard vs. soft tools of quality management, scope of implementation, and internal vs. external focus. To date, research addressing the importance of the contingency approach to implementing TQM has emphasized relationships to quality performance rather than innovation performance (Demirbag et al., 2006; Feng et al., 2006; Forker et al., 1996 and 1997; Hendricks and Sighal., 1997 and 2001; Kaynak, 2006; Prajogo, 2005; Prajogo and Brown, 2006; Samson and Terziovski, 1999; Shrivastava et al., 2006). Lewis et al. (2006 a and b) examined the use of 'hard' (analytical) factors as opposed to 'soft' (human-centered) factors. Their research concluded that a holistic approach was best to ensure proper TQM implementation.

From the standpoint of evaluating the extent of implementation of TQM in firms, key limitations in the existing research have been the inability to capture the key contextual differences for firms combined with the difficulty in addressing the multitude of performance outputs desired from a quality management system. To address the first issue, there is growing recognition that there is no single approach to TQM that can accommodate the vast differences in context and strategy that exist from firm to firm (Ahire et al., 1996; Benson et al., 1991). For researchers interested in exploring the impact of quality on organizational performance, there are numerous potential dimensions that could be explored with respect to organizational performance. In today’s business environment, many have argued that innovation must be added to the growing list of essential organizational performance metrics (Hovgaard and Hansen, 2004). 
However, a key gap in the research conducted to date is lack of detail in how specific quality management principles and practices are related to quality and innovation performance. That is, many researchers have explored relationships between quality and innovation, however there has been little work to identify specifically how companies might adapt their quality management practices to achieve innovation performance in addition to quality performance. In particular and based on the review of the literature, the following propositions are made related to the TQM dualities presented previously:

1. Firms that use a mixture of hard and soft tools will outperform (with respect to quality and innovation performance) firms that use primarily hard tools.

2. Firms that have implemented TQM companywide will outperform firms that have implemented TQM more narrowly (i.e., holistic vs. continuous improvement TQM)

3. Firms for which the focus is both internal and external will outperform firms with primarily an internal focus.

\section{Materials \& Methods}

A two-phase research project was conducted. The goal of Phase 1 was to identify firms in two broad categories - a) firms that are effectively achieving quality but not innovation outputs and b) firms that are effectively achieving both quality and innovation outputs. The goal of Phase 2 was to conduct case studies with several firms in each category and analyze the results to identify similarities and differences in quality management practices. The overall goal was to identify specific practices used by companies successfully achieving both quality and innovation performance. Details for each phase are described below. 


\section{Phase 1 - Identification of Case Firms}

Forest products manufacturers were surveyed about their quality management practices as well as their performance with respect to quality and innovation. A questionnaire developed and used previously by Prajogo and Sohal (Prajogo and Sohal, 2006a) was used. Leavengood and Anderson (2011) details how DEA was utilized to analyse the survey data and come up with the company clusters. “Quality-oriented” and "balanced” clusters were identified by examining the average quality and innovation performance responses in the questionnaire for the efficient firms. 'Balanced' firms were determined to be those with an average of five on a five-point scale for quality performance and four or higher on innovation overall. ‘Quality-oriented firms’ were determined to be those firms with an average questionnaire response of five for quality performance and 2.5 or lower for innovation.

\section{Phase 2 - Case Studies}

Firms in each category were contacted and asked to participate in the research. Data for the case studies included the firms' survey responses, in-person interviews with a senior manager in each firm, and information from company websites and other third-party information about firms available on the Internet.

Interview questions were developed to explore in greater depth each of the input and output areas from the questionnaire (e.g., questions on specific practices related to employee training, etc.) as well as to ensure each firm was categorized accurately. For example, managers were asked 
about specific examples of product and process innovations; if properly categorized, 'balanced' firms would be able to provide such examples whereas ‘quality-oriented' firms would not.

Interview questions were pilot tested with five industry experts to ensure clarity; questions were revised based on feedback received. In-person interviews were then conducted at each firm that lasted between 90 and 120 minutes. Each interview was audio recorded and transcribed verbatim. All data (interview transcripts and web-based information) were then input into qualitative research software and coded to assign responses into categories related to each of the broader propositions presented above (e.g., statements related to use of hard vs. soft tools, external vs. internal focus, etc.) as well as for specific practices within each input area (e.g., responses related to employee empowerment, measurement of customer satisfaction, etc.). While the process was iterative rather than linear, in general, data were first analyzed within-case and then cross-case as described below.

\section{Within-Case Analysis}

Transcripts and other data from each case firm were read through line by line four times - the first time as they were being transcribed and then three additional times during coding. For the interview transcripts, responses to questions were coded by the theme of the question; for the management practices, the themes included People Management (communication, employee empowerment, employee satisfaction, training in general, and cross training), Customer Focus (coded as such), and Information \& Analysis (performance measures and benchmarking). Themes related to Process Management were primarily an indication of the extent of usage of the 'hard' quality tools and thus addressed Proposition 1 described above. 
For the additional (web-based) information, transcribed information was reviewed for themes. For the most part, the web-based information was coded with regards to the output measures of quality and innovation performance given that this is what companies and third-parties tend to discuss in their publicly-available communications.

In addition to coding for the input measures (management practices), within-case analysis also involved coding for the output measures - Quality, Product Innovation (including the approach to new product development), Process Innovation, and Business Systems Innovation. The coding of these output measures also served to validate the categorization of the case firms as discussed above.

With regards to the three propositions described in the introduction, coding was conducted with a specific intent to address these propositions. For example, for Proposition 1 ('hard vs. soft' factors of TQM), only in a few instances were there essentially 'yes/no' responses that would enable coding on the hard vs. soft factors. For example, one interview question asked which of a list of tools (all of which were 'hard' factors) a company used. A 'yes' answer to this question, combined with details on where and how a tool or tools were used, served as one piece of evidence of a firm's emphasis on hard tools. By contrast, most other instances of hard vs. soft factor emphasis were implicit in a response to a question such, "How do you obtain input/feedback from customers?” A detailed response to this question would serve as evidence of a firm's emphasis on this specific soft factor. By contrast, inability to provide details served as evidence of lack of emphasis on this factor. In particular, interview questions related to 
People Management, Customer Focus, Process Management, and Information \& Analysis were identified as being the primary sources for evidence (or lack of) of soft or hard factor emphasis. At the same time, all questions had the potential to serve as evidence for this proposition depending on the comments of the interviewee. A similar approach was followed for the other two propositions.

\section{Cross-Case Analysis}

Following coding within-cases, all the survey responses for each case firm were examined again to identify key areas of similarities and differences between case firms. Interview responses were then examined for each coding theme (e.g., 'benchmarking', 'employee empowerment', etc.) to explore similarities and differences between case firms. For example, the qualitative research software allows for combining all the quotes related to any individual theme such as 'customer focus.' These documents were reviewed and notes made related to similarities and differences. It was during this process that the main differences in practices between balanced and quality-oriented firms began to emerge. As stated by Eisenhardt (1989), the key feature for this stage of the analysis is the 'chain of evidence'. For this research, the first 'link in the chain' is the company's response to the survey. For example, a company might have rated their practices related to 'employee empowerment' very high. This is evidence of commitment to this practice; however additional evidence, and detail, are needed to validate this questionnaire response. The next, and most compelling, 'links in the chain' on this theme are direct quotes from interviewees related to the topic. Other links in the chain included data from other sources such as websites that are related to the theme. To the extent that multiple sources agree, there is a 'chain of evidence' supporting the use of the practice. 


\section{Results}

The final sample frame (excluding firms that were no longer in business, bad addresses, etc.) included 2654 companies. A total of 215 firms responded (137 to the first mailing and 78 to the second) for a response rate of approximately eight percent. The majority of the questionnaires were returned via self-addressed stamped envelope - only 10 firms responded using the webbased version of the survey and four by fax.

Results of the t-test for non-response bias support the absence of a response bias ( $p>0.05)$ for 44 of the 45 mail survey questions. The one exception was the question related to 'ability to obtain new sources of supply.' For this question, the t-test comparing responses of the first 30 respondents to the last 30 respondents suggests that non-respondents may be less able to obtain new sources of supply (95 percent confidence interval for difference in means [0.12 - 1.10]). Such bias is not thought to significantly impact the results of the research in that both qualityoriented and balanced firms reported success in this area.

Data envelopment analysis resulted in identification of 26 'efficient' firms. Cluster analysis on the output responses of the efficient firms revealed three candidates for 'balanced' firms - these firms had average quality scores of five (on a five-point scale) and the highest average innovation scores (all above four) of all the efficient firms. The cluster analysis also suggested two candidate ‘quality-oriented' firms. These firms also had average quality scores of five, however the firms’ average innovation scores were below 2.2. 
Each of these five firms (three balanced and two quality-oriented) was contacted to solicit their participation in an in-person interview. Two of the three balanced firms agreed to an interview as did both of the quality-oriented firms. Hence, case studies were conducted at four firms: two balanced and two quality-oriented. Characteristics of the case firms are shown in Table 1 below.

Table 1. Characteristics of Case Firms

\begin{tabular}{|l|l|l|}
\hline & Balanced & Quality-Oriented \\
\hline Years with the company & 4,5 years & 21,25 years \\
\hline Employees & $10-15, \sim 75$ & $10-15, \sim 50$ \\
\hline Industry sector & Cabinets, lumber & Trusses, remanufacturing \\
\hline
\end{tabular}

As can be seen from the table, the case firms were small companies - all four firms had 75 or fewer employees. Further, there was one relatively small company (10-15 employees) and one slightly larger company (50-75 employees) in each category. Thus, the potential for bias between balanced and quality-oriented firms based on company size is not as likely as it would be if there were, for example, large companies in one category and small companies in the other. Further, the fact that all four case firms had fewer than 75 employees appears to correspond with the target population well. That is, given that the vast majority of the firms in this industry sector are small companies (over 85 percent of the firms surveyed had fewer than 100 employees), the fact that the case firms are also small companies is desirable from the standpoint of generalizability of research findings to this industry sector.

From the standpoint of industry sectors, three of the five industry sectors are represented by the case firms - primary (lumber and remanufacturing), secondary (cabinets), and structures 
(trusses). The fact that none of the case firms represent composite products and equipment may limit the generalizability of the findings.

Interview responses confirmed the categorization of the firms, i.e., all firms provided evidence of their commitment to quality but only the balanced firms provided evidence of innovation performance. Specifically, with respect to quality, one balanced firm said, "if anybody was eyeing quality and not just low-bid, I think we were by far the best value.” And one of the quality-oriented managers repeatedly stated his company emphasizes "do it right the first time" (a well-known mantra in quality management). By contrast, with respect to innovation, the balanced firms made statements such as "the core of our business is our technology." Further, the balanced firms were able to describe in detail new products they had developed as well as process innovations such as the development of new machinery in-house as well as software for process automation. However, the quality-oriented firms expressed skepticism about innovation as evidenced by statements such as "technology is wonderful... when it's proven." In addition, neither quality-oriented firm was able to describe new products or processes they had developed.

In fact, there were apparent fundamental differences in how balanced and quality-oriented firms viewed innovation in general. Balanced firms discussed their efforts to develop new products as a means to improve product quality. For example, the cabinet manufacturer talked about new product development in the context of developing countertops that were more water resistant. Similarly, balanced firms discussed process innovation as a means to be able to produce more consistent products (one form of quality). By contrast, quality-oriented firms viewed innovation primarily as 'technology', i.e., the end, rather than a means to some broader goal. As evidence 
of that fact, interviewees in quality-oriented firms made statements such as "we focus on people over technology” and again, “technology is wonderful... when it’s proven.”

With respect to the three propositions presented above:

1. Tools (hard vs. soft) - results for this proposition were inconclusive. Support for this proposition would have included evidence that balanced firms emphasized use of both hard and soft tools while quality-oriented firms emphasized only hard tools. However, only one firm (a balanced firm) mentioned the use of hard tools. There was some evidence that balanced firms may place more emphasis on soft tools - People Management and Customer Focus in particular, as discussed below.

2. Scope (companywide vs. narrow) - there is some support for this proposition. Firms that focused on all three of the key TQM principles (People Management, Customer Focus, and Process Management) were deemed to have a wide scope whereas firms that demonstrated minimal emphasis on at least one of the areas were deemed to have a narrow scope. In this case, there was evidence that balanced firms placed more emphasis on Customer Focus. However, contrary to expectations, quality-oriented firms were somewhat moderate on Process Management.

3. Focus (internal vs. external) - there is some support for this proposition. Firms with an internal focus were those that primarily emphasized Process Management and Information \& Analysis and that took a reactive approach to Customer Focus. By contrast, firms with an external focus were those that saw the context of their firm more broadly (beyond the immediate customer) and those that took a proactive approach to 
Customer Focus. While balanced firms were more proactive with respect to Customer

Focus, all of the firms provided evidence that they see the context of their firm broadly.

In general, many of the management practices were similar in balanced vs. quality-oriented

firms. However, there were a few areas where there were noticeable differences; these areas

included Strategic Planning, Information \& Analysis (benchmarking in particular), and as

discussed above, Customer Focus. Examples of statements made by interviewees that

demonstrate the differences between firms are shown in Table 2 below.

Table 2. Key Differences between Balanced and Quality-Oriented Firms

\begin{tabular}{|c|c|c|}
\hline & Balanced & Quality-Oriented \\
\hline $\begin{array}{l}\text { Strategic } \\
\text { Planning }\end{array}$ & $\begin{array}{l}\text { "we focus on facility development, what } \\
\text { services and products to provide, market } \\
\text { development, developing strategic partnerships } \\
\text { with clients,... financial planning, business } \\
\text { control procedures.” }\end{array}$ & $\begin{array}{l}\text { "Well, to try and survive we just } \\
\text { cut costs everywhere we can." }\end{array}$ \\
\hline $\begin{array}{l}\text { Information \& } \\
\text { Analysis } \\
\text { (benchmarking) }\end{array}$ & $\begin{array}{l}\text { "We try and benchmark our uptime for a... } \\
\text { complex industrial process. We compare very } \\
\text { well. We're running around } 98.5 \% \text { of total } \\
\text { available time in a day... So we've got a really } \\
\text { really good technology and we find ways to } \\
\text { keep it running continually." }\end{array}$ & $\begin{array}{l}\text { "I don't care what my competitors } \\
\text { do. I don't look at them. I don't } \\
\text { think about them. Fifteen years } \\
\text { ago I did. And that was a } \\
\text { mistake. I think that you do what } \\
\text { you do and you run hard" }\end{array}$ \\
\hline Customer Focus & $\begin{array}{l}\text { "if we saw sticks in the air [a new home being } \\
\text { built]... we could stop by, measure it up... and } \\
\text { as long as we'd get their contact information } \\
\text { then we could do the bid. And we'd do a set of } \\
\text { drawings." } \\
\text { "our main customers, we try to get them out } \\
\text { here once a year and let them tour the facility." }\end{array}$ & $\begin{array}{l}\text { [in response to question about } \\
\text { measuring customer satisfaction] } \\
\text { "Word gets back quickly.” } \\
\text { "It's real simple - if they keep } \\
\text { buying from you, they're } \\
\text { satisfied.” }\end{array}$ \\
\hline
\end{tabular}

Perhaps the area of greatest differences between the two categories of firms was in practices related to Customer Focus. Interview data and website information enable identification of 
additional detail on specific practices in this area. These can be summarized as focusing on customer convenience/service and customer success.

With respect to customer convenience, both balanced firms had a company website whereas neither quality-oriented firm had a website. While this fact alone may say little about the firms, it is their apparent views of the purpose or function of a website that helps shed light on their differences. Both quality-oriented firms stated that they did not have a website since they did not have the capacity to take on new business (at least prior to the current recession). For example, during the interviews, one of the quality-oriented firms stated:

"We've always been local and had all the work we could handle with local. So why would we want a website?”

Quality-oriented case firm 1

Hence, the quality-oriented firms appeared to view the purpose of a website as primarily focused on attracting new customers. Of course, the two balanced firms also viewed their websites as a tool for attracting new customers. However, this was not the sole purpose for their website. Balanced firms' websites also served as a place for existing customers to be able to download documents such as architectural drawings, see videos of the firm's processes, enable contact with company personnel (outside normal business hours), etc. While neither balanced firm provided for 'e-commerce' (i.e., allowing customers to order products on their websites), they both talked about adding such capability. In short, in addition to serving as a tool to acquire new business, the balanced firms also used their websites as a proactive means to allow their customers "24-7" access. For example, one balanced case firm stated: 
"It [the website] is a really useful tool for us - after you have a conversation on the phone, have a look at our website. And we really spend a lot of time making sure our website is updated, it's full, it's complete, so they can learn about any product and any process in the company. So we do... we use it a lot."

Balanced case firm 1

Also within the area of 'customer convenience' is the practice of developing standardized product lines. Both balanced firms talked about developing standard product lines. Of course, such standardization is commonplace in that it can lead to streamlined production and lower costs; and viewed from the company's point of view, it is difficult to make a case that such practices are a service to the customer. However, both balanced firms discussed these practices in the context of how such standardization makes it easier for their customers to specify and order products:

“...we also have some equipment that makes [product lines] and we've got a group of customers that rely on us for those and it's working with them getting a standardized list... a list of standard products that we sell and a standard cost so they don't have to keep coming back to us for quotes. They just have a price list and then also communicating that, just because we've got the standard list, we can do anything in that realm. So, it's certainly customer-driven." Balanced case firm 1

"On initial bids, [company] will provide customers with four different price-level bids in three different wood species. These packages (our Bronze, Silver, Gold, and Platinum Packages) bundle materials and options in various price-points, better showing relative pricing of popular alternatives."

Balanced case firm 2 (from company website)

Also within the area of 'proactive customer focus' is the balanced firms' focus on their customers' success, in addition to their own success. Balanced firms discussed developing new products with the explicit goal of helping their customers to increase profits, gain market share, solve challenges, etc. And in addition to these emphases for new product development, balanced 
firms emphasized customer service with a focus on helping their customers be successful.

Examples of quotes to support this idea of 'focusing on customer success' include:

"we solicited a lot of opinion from our [customers] - will you be able to sell more wood? It's one thing to say this is a great feature and our customers are going to love it. But if there wasn't a strong link to being able to sell more wood, then we've just added costs..."

Balanced case firm 1

"we spent a lot of time going through the communication and understanding what our customers were saying, that did it... were these changes going to actually allow them to compete better and gain more market share?"

Balanced case firm 1

"we gave them [dentists - a new customer segment] a presentation earlier on the solid surface counter because it's nonporous, it won't support bacterial growth.”

Balanced case firm 2 - discussion of product innovation to help reduce a costly customer challenge

“when we deliver cabinets, we deliver a counter right there. The contractor doesn't have the lead time, he's not wasting 2 to 3 weeks or, when we're busy, 4 weeks."

Balanced case firm 2 - helping customers shorten lead times

\section{Conclusions}

The results of the 3 propositions, key differences highlighted above from the interviews, as well as data from the balanced firms’ websites can be summarized broadly as follows:

- $\quad$ Balanced firms were more proactive, forward-thinking, and amenable to taking risk. This was particularly the case with Customer Focus where balanced firms made significant efforts, and took a fair amount of risk, to obtain new customers.

- Quality-oriented firms were generally reactive, focused on meeting present needs, and risk-averse. While it was clear that these companies also focused on their customers, the primary focus was on existing customers rather than in pursuing new customers. 
One unanticipated finding of this research was that the quality-oriented firms had not in fact, 'missed the boat' with regards to innovation, but rather deliberately chose not to pursue innovation. In fact, the quality-oriented firms discussed their success in the present recession as being due in large part to not having incurred debt due to investing in 'technology.' By contrast, the balanced firms discussed such labor-saving and quality-focused innovations as being a key success factor for their firms. Hence, a prerequisite for the following recommendations is that firms include innovation as part of their competitive strategy.

Findings from this research suggest that managers desiring to adapt their current quality management practices to achieve both quality and innovation performance should:

- Change how the firm views innovation - from seeing innovation as simply 'technology' to seeing innovation as a means to achieve quality and profitability

- Work to alter the company culture such that it is more amenable to risk, forwardthinking, and proactive. For example:

o Engage in strategic planning that goes beyond cost-cutting; seek to identify longer-term trends that may impact the firm and how the company might respond

o Benchmark competitors - much can be learned about best practices from firms within and beyond a firm's industry sector

o Proactively focus on customers - this is perhaps the most significant difference between the balanced and quality-oriented firms. Managers should work to ensure their company takes the initiative to identify, communicate, and respond to the needs of current as well as potential customers. Some specific actions firms can take here include creating websites with a focus not only on acquiring new 
customers but also as a service to existing customers. The website should enable customers to contact company personnel, download documents such as product drawings and specifications and price lists for standard products. In short, the website emphasizes customer convenience - making it easy for customers to do business with the firm, obtain needed information when it is needed, etc. Firms may also consider standardizing their product lines to make it easier for their customers to place orders on-line. In the area of new product development, firms that sell business-to-business may also develop new products with a focus on ensuring their customers' success. For example, firms interviewed in this research asked if their new product features would help their customers sell more products, gain market share, or solve common (and costly) problems. Lastly, services to customers such as delivering a complete product package (e.g., a cabinet manufacturer delivering a countertop at the same time as the cabinets) may help reduce customers’ lead time.

\section{Limitations}

There are three primary limitations for this research with respect to generalizability of the findings. First, as with much research in recent years involving surveys, low response rate is a limitation for the research reported here. Efforts to increase response rate (e.g., sending a second mailing to non-respondents and allowing respondents to reply either by self-addressed stamped envelope, by a web-based form, or by fax) were only moderately successful. Researchers studying a broad array of sectors have reported on problems with low response rate with regards to mail surveys (Larson, 2005). Combined with this fact, the present research was conducted 
during one of the most severe global economic recessions in decades, and the industry sector studied here was particularly hard hit. These facts surely impacted response rate as well. At the same time, response rate is not as significant a limitation as it would be had the objectives of the research been to report on trends in the target population. Given that the survey was conducted primarily to aid in identification of case firms, the potential limitation of a low response rate is with respect to how well the method used led to identification of quality-oriented and balanced case firms. Findings suggest that the quality-oriented firms provided strong evidence of their focus on quality but not innovation and the balanced firms provided strong evidence of a focus on both quality and innovation. Hence, the low response rate to the survey was not deemed to be a significant limitation.

Secondly, with respect to generalizability, an additional limitation is the small number of firms examined in the cases. In this regard, the method used to select case firms had both strengths and weaknesses. A strength of the approach is that, rather than using a subjective method to select case firms, the survey enabled an objective approach to case firm selection and minimized potential for researcher bias in selecting case firms. At the same time, the case selection method also resulted in identification of only 2 candidate firms in the quality-oriented category and 3 in the balanced category. And for the balanced firms, 1 of the 3 firms scaled-back their operation to focus solely on retail during the course of the research. In short, the method used to select case firms resulted in a pool of only four case firms. Clearly a larger number of case firms would be desirable to obtain more depth and breadth in the findings. 
Lastly, the findings here are also limited with respect to industry sector. The forest products industry was selected for the research due to the first author's background and experience working with this sector. However, the authors acknowledge that the traditional nature of this industry limits the generalizability of the findings. At the same time, many of the findings here have been confirmed by researchers exploring other industry sectors. Therefore, as with the limitation on survey response rate, this limitation was also deemed not to be significant. 


\section{References}

S. L. Ahire, R. Landeros, and D. Y. Golhar, "Total quality management: A literature review and an agenda for future research," Production and Operations Management, vol. 4, pp. 277306, Summer 1995.

S. L. Ahire, D. Golhar, and M. A. Waller, "Development and validation of TQM implementation constructs," Decision Sciences, vol. 27, pp. 23-56, Winter 1996.

Anonymous. (2006, October 11). Quality Glossary. Available:

http://www.asq.org/glossary/q.html

P. G. Benson, J. V. Saraph, and R. G. Schroeder, "The effects of organizational context on quality management: An empirical investigation," Management Science, vol. 37, pp. 1107-1124, September 1991.

S. Black and L. J. Porter, "An empirical model for total quality management," Total Quality Management, vol. 6, pp. 149-164, 1995.

B. A. G. Bossink, "The strategic function of quality in the management of innovation," Total Quality Management, vol. 13, pp. 195-205, 2002.

R. E. Cole and T. Matsumiya, "Too much of a good thing? Quality as an impediment to innovation," California Management Review, vol. 50, pp. 77-93, Fall 2007.

R. E. Cole and T. Matsumiya, "When the pursuit of quality risks innovation," The TQM Journal, vol. 20, pp. 130-142, 2008.

R. G. Cooper, "Overhauling the new product process," Industrial Marketing Management, vol. 25, pp. 465-482, 1996. 
M. Demirbag, E. Tatoglu, M. Tekinkus, et al., "An analysis of the relationship between TQM implementation and organizational performance: Evidence from Turkish SMEs," Journal of Manufacturing Technology Management, vol. 17, pp. 829-847, 2006.

K. M. Eisenhardt, "Building theories from case study research," Academy of Management Review, vol. 14, pp. 532-550, 1989.

J. R. Evans and W. M. Lindsay, The Management and Control of Quality, Fifth ed. Cincinnati: South-Western Publishing, 2002.

J. Feng, D. I. Prajogo, K. C. Tan, et al., "The impact of TQM practices on performance: A comparative study between Australian and Singaporean organizations," European Journal of Innovation Management, vol. 9, pp. 269-278, 2006.

B. B. Flynn, R. G. Schroeder, and S. Sakakibara, "A framework for quality management research and an associated measurement instrument," Journal of Operations Management, vol. 11, pp. 339-366, 1994.

L. B. Forker, S. K. Vickery, and C. L. M. Droge, "The contribution of quality to business performance," International Journal of Operations \& Production Management, vol. 16, pp. 44-62, 1996.

L. B. Forker, D. Mendez, and J. C. Hershauer, "Total quality management in the supply chain: What is its impact on performance?," International Journal of Production Research, vol. 35, pp. 1681-1701, 1997.

C. B. Fotopoulos and E. L. Psomas, "The impact of "soft” and "hard” TQM elements on quality management results," International Journal of Quality \& Reliability Management, vol. 26, pp. 150-163, 2009.

D. A. Garvin, "Quality on the line," Harvard Business Review, 61(3): 64-75. 1983. 
H. H. Goldman, "The origins and development of quality initiatives in American business," The TQM Magazine, vol. 17, pp. 217-225, 2005.

K. B. Hendricks and V. R. Singhal, "Does implementing an effective TQM program actually improve operating performance? Empirical evidence from firms that have won quality awards," Management Science, vol. 43, pp. 1258-1274, September 1997.

K. B. Hendricks and V. R. Singhal, "The long-run stock price performance of firms with effective TQM programs," Management Science, vol. 47, pp. 359-368, March 2001.

D. T. Hoang, B. Igel, and T. Laosirihongthong, "The impact of total quality management on innovation: Findings from a developing country," International Journal of Quality \& Reliability Management, vol. 23, pp. 1092-1117, 2006.

A. Hovgaard and E. Hansen, "Innovativeness in the forest products industry," Forest Products Journal, vol. 54, pp. 26-33, January 2004.

G. K. Kanji, "Can Total Quality Management help innovation?," Total Quality Management, vol. 7, pp. 3-9, 1996.

H. Kaynak, "Measuring organisational effectiveness and business performance in firms implementing total quality management," International Journal of Manufacturing Technology \& Management, vol. 8, pp. 355-381, 2006.

T. Kekale and J. Kekale, "A mismatch of cultures: A pitfall of implementing a total quality approach," International Journal of Quality \& Reliability Management, vol. 12, pp. 210220, 1995.

P.D. Larson, "A note on mail surveys and response rates in logistics research," Journal of Business Logistics, vol. 26, pp. 211-222, 2005. 
S. Leavengood and T.R. Anderson "Best Practices in Quality Management for Innovation Performance." In In D.F. Kocoaglu, T.R. Anderson, \& T.U. Daim (Eds.), Technology Management in the Energy Smart World, Portland International Conference on Management of Engineering and Technology Proceedings, Portland, Oregon (pp. 22472255). IEEE Press.

W. G. Lewis, K. F. Pun, and T. R. M. Lalla, "Exploring soft versus hard factors for TQM implementation in small and medium-sized enterprises," International Journal of Productivity and Performance Management, vol. 55, pp. 539-554, 2006a.

W. G. Lewis, K. F. Pun, and T. R. M. Lalla, "Empirical investigation of the hard and soft criteria of TQM in ISO 9001 certified small and medium-sized enterprises," International Journal of Quality \& Reliability Management, vol. 23, pp. 964-985, 2006b.

Liao S, Chang W and Wu C, " Exploring TQM-Innovation relationship in continuing education: A system architecture and propositions", Total Quality Management \& Business ExcellenceVolume 21, Issue 11, November 2010, pages 1121-1139

Martínez-Costa M and Martínez-Lorente A.R. " Does quality management foster or hinder innovation? An empirical study of Spanish companies", Total Quality Management \& Business ExcellenceVolume 19, Issue 3, March 2008, pages 209-221

K. McManus, "Is quality dead?," IIE Solutions, vol. 31, pp. 32-35, July 1999.

R. McAdam, G. Armstrong, and B. Kelly, "Investigation of the relationship between total quality and innovation: A research study involving small organisations," European Journal of Innovation Management, vol. 1, pp. 139-147, 1998.

NBC, "If Japan Can, Why Can't We?," in NBC White Paper, ed: CC-M, 1980. 
NIST, "Criteria for Performance Excellence, Malcolm Baldrige National Quality Program," National Institute of Standards and Technology. 2009.

D. I. Prajogo, "The comparative analysis of TQM practices and quality performance between manufacturing and service firms," International Journal of Service Industry Management, vol. 16, pp. 217-228, 2005.

D. I. Prajogo and A. Brown, "Approaches to adopting quality in SMEs and the impact on quality management practices and performance," Total Quality Management, vol. 17, pp. 555566, June 2006.

D. I. Prajogo and A. S. Sohal, "TQM and innovation: A literature review and research framework," Technovation, vol. 21, pp. 539-558, 2001.

D. I. Prajogo and A. S. Sohal, "The relationship between TQM practices, quality performance, and innovation performance: An empirical examination," International Journal of Quality \& Reliability Management, vol. 20, pp. 901-918, 2003.

D. I. Prajogo and A. S. Sohal, "Transitioning from total quality managment to total innovation management: An Australian case," International Journal of Quality \& Reliability Management, vol. 21, pp. 861-875, 2004.

D. I. Prajogo and A. S. Sohal, "The relationship between organization strategy, total quality management (TQM), and organization performance - the mediating role of TQM," European Journal of Operational Research, vol. 168, pp. 35-50, 2006.

D. I. Prajogo and A. S. Sohal, "The integration of TQM and technology/ R\&D management in determining quality and innovation performance," Omega: The International Journal of Management Science, vol. 34, pp. 296-312, 2006. 
H. E. Samaha, "Overcoming the TQM barrier to innovation," HR Magazine, vol. 41, pp. 145149, June 1996.

D. Samson and M. Terziovski, "The relationship between total quality management practices and operational performance," Journal of Operations Management, vol. 17, pp. 393-409, 1999.

R. Sethi and A. Sethi, "Can quality-oriented firms develop innovative new products?," Journal of Product Innovation Management, vol. 26, pp. 206-221, 2009.

P. J. Singh and A. J. R. Smith, "Relationship between TQM and innovation: An empirical study," Journal of Manufacturing Technology Management, vol. 15, pp. 394-401, 2004.

S. B. Sitkin, K. M. Sutcliffe, and R. G. Schroeder, "Distinguishing control from learning in Total Quality Management: A contingency perspective," Academy of Management Review, vol. 19, pp. 537-564, 1994.

R. L. Shrivastava, R. P. Mohanty, and R. R. Lakhe, "Linkages between Total Quality Management and organisational performance: An empirical study for Indian industry," Production Planning and Control, vol. 17, pp. 13-30, January 2006. 